\title{
PENGARUH PERAN KEPALA SEKOLAH SEBAGAI SUPERVISOR AKADEMIK TERHADAP KINERJA GURU DI SMK PGRI TANJUNG RAJA
}

\author{
${ }^{1}$ Sepriadi dan ${ }^{2}$ Syarwani Ahmad \\ ${ }^{1}$ Peneliti Magister Manajemen Pendidikan, Universitas PGRI Palembang \\ ${ }^{2}$ Dosen Program Studi Magister Manajemen Pendidikan, Universitas PGRI Palembang \\ e-mail: seprisoni@ymail.com
}

\begin{abstract}
This study aimed at determining (1) leadership of headmaster's Vocational School of PGRI Tanjung Raja as academic supervisor; (2) the teachers' performance of Vocational School of PGRI Tanjung Raja; and (3) the influence of headmaster's leadership on the teachers' performance of Vocational School of PGRI Tanjung Raja. This research was quantitative research with expostfacto approach. The population in this study were the teachers of Vocational School PGRI Tanjung Raja consist of 85 teachers and then the sample was 60 teachers which selected by area proportional random sampling technique. The data collection instrument was questionnaire with Likert scale which has 4 alternative answers, on 100 items. The data analysis was used simple regression analysis technique. The results showed (1) leadership of headmaster's Vocational School of PGRI Tanjung Raja according to some teachers (52\%) high category; then (2) the teachers' performance of Vocational School PGRI Tanjung Raja (52\%) high category; and (3) there is a positive and significant influence of headmaster leadership as academic supervisor on teachers' performance 65,1\% happened to teacher's performance can be explained by headmaster leadership as academic supervisor, while 80,7\% other explained by other variable not included in this study such as teacher's knowledge, teachers' personality, dedication, professional development, and so forth.
\end{abstract}

Kata Kunci: Headmaster's Leadership, Teachers' Performance, Vocational School PGRI Tanjung Raja

\section{PENDAHULUAN}

Penelitian ini berawal dari peran pendidikan supaya dapat berkualitas sebagai salah satu faktor penting yang harus dipenuhi yaitu keberadaan guru, kepala sekolah yang bermutu, yang professional, sejahtera dan bermartabat menurut Mulyasa (2009: 4-6). Kepala sekolah sebagai supervisor mempunyai kemampuan untuk menciptakan situasi belajar mengajar sedemikian rupa, sehingga dapat mencapai tujuan pendidikan. Tanggung jawab pembinaan guru atau supervisi banyak berada ditangan kepala sekolah disebabkan oleh suatu kenyataan bahwa kepala sekolah yang setiap hari bergaul dan bekerja sama dengan guruguru. Kepala sekolah bertanggung jawab penuh terhadap kelancaran pelaksanaan pendidikan dan akademik di sekolah. Menurut Azis Wahab (2009), bahwa "dalam perannya sebagai supervisor kepala sekolah diharapkan dapat membantu rekan-rekan guru secara profesional untuk mengatasi berbagai persoalan belajar mengajar.

Kepala sekolah sebagai orang yang berwenang dan bertanggung jawab terhadap keberhasilan proses belajar mengajar, dapat 
membaca dan mengatasi permasalahan yang dihadapinya, sehingga guru terlepas dari kemelut yang dapat mempengaruhi kelancaran tugasnya. Kepala sekolah selaku Supervisor akademik dalam usahanya memberikan bantuan atau pelayanan profesional kepada guru selalu menaruh perhatian yang sungguhsungguh terhadap aspek-aspek yang dapat mengganggu tugas guru dalam proses belajar mengajar. Dalam hal ini, kepala sekolah senantiasa mempelajari secara obyektif dan terus menerus masalah-masalah yang menjadi kendala guru dalam pelaksanaan tugasnya. Wahjosumidjo (1994) menyatakan bahwa apabila seorang kepala sekolah ingin berhasil menggerakkan para guru dalam menjalankan tugasnya, maka : 1. Menghindarkan diri dari sikap dan perbuatan memaksa atau bertindak keras terhadap guru, 2. Harus mampu melakukan perbuatan yang melahirkan kemauan untuk bekerja dengan penuh semangat dan percaya diri terhadap guru dengan: menyakinkan (persuade) dan membujuk (induce) bahwa apa yang dilakukan adalah benar. Keinginan guru untuk tumbuh dan berkembang begitupun kualitas tugas sesuai dengan kompetensi profesional menuntut perhatian dari kepala sekolah untuk dapat menjaring dan memenuhi kebutuhan tersebut. Kepala sekolah dituntut membantu menciptakan iklim yang kondusif bagi pertumbuhan profesional guru sehingga guru terbebas dari rasa takut, ancaman atau paksaan. Untuk itu kepala Sekolah dapat menggunakan pola pendekatan yang sesuai dengan kebutuhan dan karakteristik guru. Berdasarkan pemikiran tersebut di atas, maka fungsi dan peranan kepala sekolah sebagai supervisor dan pemimpin pendidikan akan efektif apabila (1) melakukan program intruksional akademik secara efektif, (2) melalui kepemimpinan yang dinamis, (3) mengacu proses pembelajaran guru, (4) membantu menciptakan iklim yang kondusif bagi pertumbuhan professional guru, (5) menggunakan pola pendekatan yang sesuai kebutuhan dan karakteristik guru, (6) dan memberikan bantuan kepada guru secara langsung melalui kunjungan kelas, pembicaraan/bimbingan individual pemberian petunjuk tentang cara memajukan proses belajar mengajar. Faktor kemampuan atau kompetensi kepala sekolah dalam supervisi sangat menentukan terlaksananya kegiatan supervisi akademi di sekolahnya masingmasing. Kompetensi itu meliputi pengetahuan tentang supervisi, kemampuan dalam hubungan antar pribadi dan keterampilan teknis dalam supervisi. Ketiga hal tersebut merupakan faktor kemampuan yang mutlak dimiliki oleh setiap kepala sekolah sebagai supervisor akademik.

Supervisi terhadap guru dimaksudkan untuk melakukan pembinaan dan 
pengembangan terhadap guru sebagai salah satu komponen sekolah. Hasil penelitian Liphan sebagai mana yang dikutip oleh Syaiful Sagala (2010) berkaitan dengan kinerja kepala sekolah menyatakan bahwa kepala Sekolah yang berhasil adalah kepala yang memiliki komitmen yang kuat terhadap peningkatan kualitas akademik. Komitmen yang kuat menggambarkan adanya kemauan dan kemampuan melakukan monitoring pada semua aktivitas personel sekolah. Oleh karena itu agar diperoleh kualitas pendidikan yang sesuai dengan tujuan yang telah ditetapkan maka guru dituntut untuk selalu memiliki kinerja yang tinggi. Dalam kaitannya dengan peranan kepemimpinan dalam meningkatkan kinerja guru, perlu dipahami bahwa setiap pemimpin bertanggung jawab mengarahkan apa yang baik bagi pegawainya, dan dia sendiri harus berbuat baik. Pemimpin dalam hal ini kepala sekolah harus juga memberi contoh, sabar, dan penuh pengertian. Fungsi pemimpin hendaknya diartikan seperti motto Ki Hadjar Dewantara: ing ngarsa sung tulada, ing madya mangun karsa, tut wuri handayani (di depan menjadi teladan, di tengah memberi kemauan, dibelakang menjadi pendorong atau memberi daya). Kinerja guru merupakan hasil kerja dan kemajuan yang dicapai oleh guru dalam melaksanakan tugas dan kewajibanya. Kinerja yang baik itu diantaranya terlihat dari guru yang ingin hadir ke sekolah dan rajin dalam mengajar, guru mengajar dengan sungguh-sungguh menggunakan rencana pelajaran, guru mengajar dengan semangat dan senang hati, menggunakan metode yang bervariasi sesuai dengan materi pelajaran, melakukan evaluasi pengajaran dan menindak lanjuti hasil evaluasi.

Kinerja guru yang tinggi ini akan banyak memberikan pengaruh yang kuat terhadap keberhasilan peserta didik dalam mencapai tingkat kompetensinya. Namun demikian, kinerja guru juga disangkutpautkan dengan kepemimpinan kepala sekolah, komunikasi antar sesama guru dan kepala sekolah dapat dikatakan kurang berjalan dengan baik, kepala sekolah kurang memberikan motivasi yang penuh terhadap guru sehingga terkadang guru masih enggan untuk mengembangkan tingkat profesionalitasnya. Dengan kondisi seperti ini, otomatis akan terjadi pergeseran peran guru dalam proses pengembangan potensi peserta didik, yakni guru hanya sebagai pembekal informasi bagi peserta didik. Hal ini tidak terlepas dari pengaruh kepemimpinan kepala sekolah dalam menjalankan kepemimpinannya (Arimbi, 2011).

Dari beberapa penelitian yang berkaitan mengenai kepemimpinan kepala sekolah dan kinerja guru, disebutkan bahwa kepemimpinan kepala sekolah memiliki hubungan, pengaruh dan sumbangan terhadap 
kinerja guru. Hubungan kepemimpinan kepala sekolah dan kinerja guru dibuktikan dengan penelitian yang dilakukan oleh Sri Kustilah (2005: 2) dalam penelitiannya yang berjudul "Kontribusi Kesejahteraan Guru, Iklim Kerja, dan Kepemimpinan Kepala Sekolah terhadap Kinerja Guru IPS SMP di Kota Yogyakarta”. Penelitian memperlihatkan bahwa adanya sumbangan efektif antara kesejahteraan guru, iklim kerja dan kepemimpinan kepala sekolah terhadap kinerja guru. Selanjutnya penelitian Yuliandri dan Kristiawan (2016) yang berjudul "Peran Kepemimpinan Kepala Sekolah Terhadap Peningkatan Kinerja Guru” menyebutkan bahwa faktor-faktor yang mempengaruhi kinerja guru dapat berasal dari dalam seperti kemampuan, motivasi, keterampilan, kedisiplinan dan pendidikan. Ada juga faktor dari luar seperti iklim kerja, budaya organisasi, kepemimpinan, jaminan sosial dan tingkat penghasilan.

Kemudian penelitian yang dilakukan oleh Imam Erfendi (2005: 2) yang berjudul "Pengaruh Pengalaman Guru, Motivasi dan Kepemimpinan Kepala Sekolah terhadap Kinerja Guru Sekolah Dasar di Kecamatan Tenggarong Kabupaten Kutai Kartanegara”. Penelitian tersebut memperlihatkan bahwa pengalaman guru, motivasi dan kepemimpinan kepala sekolah berpengaruh positif dan signifikan terhadap kinerja guru. Selain itu penelitian dari Fredikus Djelahu Maigahoaku
(2010: 135) dengan judul "Sumbangan Kepemimpinan Kepala Sekolah,Iklim Sekolah, dan Kompetensi Guru terhadap Kinerja Guru Sekolah Menengah Atas di Kabupaten Manggarai”, penelitiannya memperlihatkan kepemimpinan kepala sekolah sebagai salah satu variabel bebas penelitian memiliki hubungan yang positif dengan kinerja guru. Maka untuk meningkatkan kompetensi guru professional di sekolah, guru sangat memerlukan bantuan dan bimbingan dari kepala Sekolah salah satu diantaranya adalah dalam bentuk kegiatan supervisi akademik. Berdasarkan pengamatan di SMK PGRI Tanjung Raja, bahwa kinerja guru cukup baik, salah satunya disebabkan oleh supervisi kepala sekolah telah melaksanakan supervisi akademik.

\section{PERAN KEPEMIMPINAN KEPALA SEKOLAH}

Berawal dari Kepala sekolah harus berprestasi terutama bekaitan dengan profesionalisme, dalam hal ini dapat diukur dari segi yaitu : (a) keberhasilan mengajar. (b) kualifikasi pendidikan minimal memiliki kualifikasi akademik setara (S1) atau diploma empat (D-IV) kependidikan atau non kependidikan pada perguruan tinggi yang terakreditasi hal ini sesuai dengan peraturan menteri pendidikan No.13 tahun 2007 tentang Standar Kepala Sekolah / Madrasah. Pemimpin yang berhasil adalah pemimpin 
yang dapat memadukan rasa kebersamaan bawahannya, sehingga mereka dapat bekerja dengan baik tanpa paksaan serta memahami tanggung jawabnya. Oleh karena itu seorang pemimpin harus mempunyai bekal keahlian dan pengalaman dalam memimpin, sehingga tidak mendapat kesulitan dalam mengendalikan bawahannya.

Di samping dapat membaca keinginan dan kehendak dari bawahannya serta mengerti apa yang harus diberikan kepada bawahannya, juga dapat mengerti akan tujuan pimpinannya. Karena untuk memegang jabatan pimpinan tidak semudah yang diduga. Pemimpin dituntut untuk dapat membangkitkan perasaan dan keinginan bawahan agar dapat bekerja tanpa beban paksaan, dan tidak ditanggapi perasaan takut dalam bekerja. Pemimpin yang berhasil adalah pemimpin yang dapat memadukan rasa kebersamaan bawahannya, sehingga mereka dapat bekerja dengan baik tanpa paksaan serta memahami tanggungjawabnya. Oleh karena itu seorang pemimpin harus mempunyai bekal keahlian dan pengalaman dalam memimpin, sehingga tidak mendapat kesulitan dalam mengendalikan bawahannya. Disamping dapat membaca keinginan dan kehendak dari bawahannya serta mengerti apa yang harus diberikan kepada bawahannya, juga dapat mengerti akan tujuan pimpinannya. Karena untuk memegang jabatan pimpinan tidak semudah yang diduga. Pemimpin dituntut untuk dapat membangkitkan perasaan dan keinginan bawahan agar dapat bekerja tanpa beban paksaan, dan tidak ditanggapi perasaan takut dalam bekerja (Arimbi, 2011).

Kartini Kartono (1990: 56) menyebutkan bahwa ada delapan tipe kepemimpinan sebagai berikut: a) Tipe Karismatis , tipe pemimpin karismatis memiliki kekuatan energi daya tarik dan pembawa yang luar biasa untuk mempengaruhi orang lain, sehingga mempunyai pengikut yang sangat besar jumlahnya dan pengawal-pengawal yang bisa dipercaya. Sampai sekarang pun orang tidak mengetahui benar sebab-sebabnya, mengapa seseorang itu memiliki karisma begitu besar. Dia dianggap mempunyai kekuatan ghaib (supernatural power) dan kemampuankemampuan yang superhuman, yang diperoleh sebagai karunia Yang Maha Kuasa. Dia banyak memiliki inspirasi, keberanian, berkeyakinan teguh pada pendirian sendiri. Totalitas kepribadian pemimpin memancarkan pengaruh dan daya tarik yang teramat besar., b) Tipe Paternalistis dan Maternalistis, tipe kepemimpinan yang kebapakan, c) Tipe militeristis ,tipe ini sifatnya sok kemiliteran. d) Tipe Otokratis atau Otoritatif kepemimpinan ini didasarkan pada kekuasaan dan paksaan yang mutlak harus dipenuhi. e) Tipe laisser Faire, kepemimpinan yang sangat praktis dan membiarkan kelompoknya serta setiap orang 
berbuat semau sendiri. f) Tipe populistis, kepemimpinan populates berpegang teguh pada nilai-nilai masyarakat yang tradisional serta mempercayai dukungan dan bantuan hutang-hutang luar negeri. g) Tipe administratif atau eksekutif, kepemimpinan yang dimaksud adalah kepemimpinan yang mampu menyelenggarakan tugas-tugas administrasi secara efektif. h) Tipe Demokratis, kepemimpinan demokratis berorientasi pada manusia dan memberikan bimbingan yang efisien kepada para pengikutnya.

\section{KINERJA GURU}

Kinerja guru merupakan perwujudan kemampuan dan keterampilan berdasarkan kewenangan yang dimilki dalam tugas pokoknya, yaitu keterampilan mengajar. Perwujudan kemampuan tersebut adalah kegiatan guru dalam proses pembelajaran yaitu merencanakan pembelajaran, melaksanakan kegiatan pembelajaran, dan menilai hasil belajar (Yuliandri dan Kristiawan, 2017).

Natawijaya (1994:38) menyatakan bahwa kinerja guru mencakup aspek: (1) kemampuan profesional dalam proses belajar mengajar; (2) kemampuan social dalam proses belajar mengajar; dan (3) kemampuan pribadi dalam proses belajar mengajar. Pendapat hampir senada dikemukakan oleh Joni yang dikutip oleh Arikunto (1990) menjelaskan bahwa ada tiga kompetensi yang harus dimiliki oleh guru, yaitu: (1) kompetensi profesional; (2) kompetensi personal; dan (3) kompetensi sosial.

\section{SUPERVISI AKADEMIK}

Menurut Purwanto (1998:76) bahwa supervisi adalah suatu aktivitas pembinaan yang direncanakan untuk membantu para guru dan pegawai sekolah lainnya dalam melakukan pekerjaan secara efektif. Sedangkan Wiyono (1989:180) mencoba mendefinisikan supervisi dengan mengkaitkan fungsi pimpinan umum yang mengkoordinasikan dan memimpin kegiatan-kegiatan sekolah yang berhubungan dengan kegiatan belajar. Hal senada dikemukakan Sahertian (2000:19) Supervisi adalah usaha memberikan pelayanan dan bantuan kepada guru-guru baik secara individual maupun secara kelompok dalam usaha memperbaiki pengajaran. Kata kunci dari pelaksanaan supervisi adalah "memberi layanan dan bantuan”. Menurut Gaffar (1987:158-159) supervisi merupakan suatu keharusan untuk mengatasi permasalahan tugas di lapangan. Supervisi menekankan kepada pertumbuhan profesional dengan inti keahlian teknis serta perlu ditunjang oleh kepribadian dan sikap profesional. Berkaitan dengan materi pembinaan tersebut, Oliva (1987:18) menegaskan bahwa pondasi supervisi pendidikan adalah teknologi 
pembelajaran, teori kurikulum, interaksi kelompok, konseling, sosiologi, disiplin ilmu, evaluasi, manajemen, teori belajar, sejarah pendidikan, teori komunikasi, teori kepribadian, dan filsafat pendidikan. Disamping itu, supervisi seharusnya merupakan program yang didesain oleh sekolah maupun organisasi pembantu dan penyelenggaraan pendidikan serta didukung oleh kegiatan yang diadakan oleh pihak guru

Menurut Soewadji (1987:42) "teknik supervisi ada beberapa macam, yaitu (1) observasi kelas, (2) percakapan individu/kelompok, (3) saling berkunjung, (4) diskusi, (5) rapat guru, (6) kunjungan studi". Sahertian (2000:53) membedakan teknik supervisi menjadi dua yaitu teknik supervisi yang bersifat individual dan kelompok. Teknik supervisi yang bersifat individual ada tiga jenis yaitu: (1) kunjungan kelas, (2) observasi, (3) percakapan pribadi. Sedangkan teknik yang bersifat kelompok antara lain: rapat guru, diskusi kelompok, loka karya, seminar, simposium, dan sebagainya. Menurut Purwanto (2004: 118), ada beberapa faktor yang mempengaruhi berhasil tidaknya supervisi atau cepat lambatnya hasil supervisi, antara lain: 1) Lingkungan masyarakat tempat sekolah itu berada, 2) Besar kecilnya sekolah yang menjadi tanggung jawab kepala sekolah, 3) Tingkatan dan jenis sekolah, 4) Keadaan para guru dan pegawai yang tersedia, 5)
Kecakapan dan keahlian kepala sekolah itu sendiri.

\section{METODE PENELITIAN}

Penelitian ini termasuk dalam jenis penelitian kuantitatif, karena data yang diperoleh berupa angka-angka dan pengolahannya menggunakan metode statistik yang digunakan lalu diinterpretasikan. Tujuan dipilihnya pendekatan kuantitatif mengacu pada pendapat F.X. Sudarsono (1989: 9) yaitu menggambarkan suatu gejala secara kuantitatif dengan sajian skor rerata, penyimpangan, grafik dan lain-lain, serta membuat prediksi dan estimasi berdasarkan hasil analisis dan model yang telah ditetapkan. Lebih lanjut penelitian ini bersifat ex-post facto karena hanya mengungkapkan data peristiwa yang sudah berlangsung dan telah ada pada responden tanpa memberikan perlakukan atau manipulasi terhadap variabel yang diteliti. Hal ini sesuai dengan pendapat Sugiyono (2007: 3) yang menyatakan bahwa penelitian ex-post facto dilakukan untuk meneliti peristiwa yang terjadi dan kemudian meruntut ke belakang melalui data tersebut untuk menentukan sebabsebab yang mungkin atas peristiwa yang diteliti. Dalam penelitian ini peneliti berusaha menggali secara mendalam seberapa besar pengaruh variabel bebas (kepemimpinan kepala sekolah) terhadap variabel terikat (kinerja guru). Objek pada penelitian ini 
adalah SMK PGRI Tanjung Raja di Kabupaten Ogan Ilir. Selain peneliti melakukan studi dokumen terhadap prestasi siswa dan kinerja guru, peneliti juga melakukan wawancara langsung ke Kepala Sekolah dan guru. Metode pengumpulan data yang digunakan dalam penelitian ini adalah wawancara, observasi, dokumentasi dan angket. Angket disini sebagai teknik utama penelitian dan teknik pendukung penelitian berupa studi dokumentasi. Metode studi dokumentasi dalam penelitian ini digunakan untuk mengetahui jumlah guru SMK PGRI Tanjung Raja. Selanjutnya angket (questionnaire) menurut Riduwan (2007: 2526) adalah daftar pertanyaan yang diberikan kepada orang lain bersedia memberikan respons (responden) sesuai dengan permintaan pengguna. Dengan angket ini maka peneliti dapat memberikan sejumlah pertanyaan kepada responden yang sesuai dengan permasalahan dalam penelitiannya. Angket diberikan kepada guru SMK PGRI Tanjung Raja untuk mengetahui tentang data kepemimpinan kepala sekolah terhadap kinerja guru. Kemudian teknik studi dokumen yang digunakan adalah mencari data mengenai halhal yang berupa catatan, transkip, buku, surat kabar, majalah, prasasti, notulen rapat, legger, dan agenda (Arikunto, 2002). Hadari (2005) menyatakan bahwa studi dokumen adalah "cara pengumpulan data melalui peninggalan tertulis terutama berupa arsip-arsip dan termasuk juga buku mengenai pendapat, dalil yang berhubungan dengan masalah penyelidikan". Alasan digunakan angket sebagai metode utama dalam penelitian ini yaitu biaya relatif murah, waktu untuk mendapatkan data singkat, dan dapat dilakukan terhadap subjek dengan jumlah besar. Seperti yang dikemukakan oleh Sumadi Suryabrata (2003: 17-18) beberapa kelebihan dengan metode angket yaitu biaya murah, waktu untuk mendapatkan data relatif singkat, tidak dibutuhkan keahlian lapangan yang diselidiki, dan dilakukan sekaligus terhadap subjek yang jumlahnya besar.

Dalam menganalisis data, peneliti menggunakan teknik analisis statistik deskriptif dan teknik analisis regresi sederhana. Menurut Sugiyono (2007: 207) statistik deskriptif adalah statistik yang digunakan untuk menganalisis data dengan cara mendeskripsikan atau menggambarkan data yang terkumpul sebagaimana adanya tanpa bermaksud membuat kesimpulan yang berlaku untuk umum atau generalisasi. Analisis deskriptif yang dipakai dalam penelitian ini yaitu dengan mendiskripsikan data dengan distribusi frekuensi, histrogram, pengukuran nilai sentral mean (rerata), modus, median dan simpangan baku. Adapun proses analisis data dilaksanakan dengan menggunakan SPSS 24.0. Adapun langkahlangkah yang dilakukan adalah sebagai 
berikut: 1. Menentukan skor tertinggi dan skor terendah. Alternatif pilihan jawaban dari setiap item pertanyaan terdiri dari 4 jawaban.

Skor tertinggi $=\frac{4}{4} \times 100 \%=100 \%$

$$
\text { Skor terendah }=\frac{1}{4} \times 100 \%=25 \%
$$

2. Menentukan rentang data Yaitu skor tertinggi dikurangi skor terendah

Rentang data $=100 \%-25 \%=75 \%$

3. Menentukan panjang kelas interval

4. Range $($ panjang kelas $)=$ rentang data $: 4$

$$
\begin{aligned}
& =75 \%: 4 \\
& =18,75 \approx 19
\end{aligned}
$$

5. Mengelompokkan interval nilai dan melengkapinya dengan kategori kualitatif.

Tabel 1 . Kategorisasi Skor Penelitian

\begin{tabular}{cc}
\hline Interval & Kategori \\
\hline $82 \%-100 \%$ & Tinggi \\
$63 \%-81 \%$ & Sedang \\
$44 \%-62 \%$ & Cukup \\
$25 \%-43 \%$ & Rendah \\
\hline
\end{tabular}

\section{HASIL PENELITIAN DAN PEMBAHASAN}

Penelitian ini dilakukan di SMK PGRI Tanjung Raja. Visi dari SMK PGRI Tanjung Raja adalah mewujudkan peserta didik yang beriman, bersemangat, dan berdisiplin dalam proses pembelajaran untuk mengembangkan ilmu pengetahuan dan teknologi (IPTEK). Visi tersebut kemudian direalisasikan ke dalam misi SMK PGRI Tanjung Raja. Adapaun misi dari sekolah tersebut adalah membentuk kepribadian yang beraklak mulia dan bertaqwa terhadap Tuhan Yang Maha Esa, menyiapkan tenaga kerja yang berwawasan kewirausaahan dan mandiri, menghasilkan lulusan yang berguna dan memiliki semangat kebangsaan, mewujudkan tenaga kerja yang professional, disiplin, kreatif, motovatif, dan inovatif, menghasilkan lulusan yang berkualitas dan memiliki keterampilan serta siap bersaing di era global. SMK PGRI Tanjung Raja yang terakreditasi B, SMK PGRI Tanjung Raja dipimpin oleh seorang kepala sekolah, dan mempunyai 85 staf pengajar dan staf karyawan. Hampir sebagian besar guru yang mengajar di SMK PGRI Tanjung Raja merupakan lulusan S1 dan 9 orang sudah menerima sertifikasi.

Penelitian ini menggunakan dua variabel, yaitu variabel kepemimpinan kepala sekolah sebagai supervisor akademik dan kinerja guru. Kepemimpinan kepala sekolah diukur dengan menggunakan kuesioner yang diberikan kepada guru yang merupakan anggota populasi dari guru-guru SMK PGRI Tanjung Raja. Angket tersebut menggunakan model skala likert, dimana setiap jawaban memiliki skor yang berbeda. Pernyataan yang favorable pada kuesioner, untuk jawaban yang positif skornya akan semakin tinggi, dan untuk jawaban yang negatif skornya akan semakin rendah, begitu juga sebaliknya pada 
pernyataan yang unfavorable. Kinerja guru juga diukur dengan menggunakan instrumen penelitian berupa kuesioner yang diberikan kepada 60 guru yang merupakan anggota populasi dari guru-guru SMK PGRI Tanjung Raja. Variabel kinerja guru diukur dengan pertanyaan sebanyak 60 butir. Pernyataan yang favorable pada kuesioner, untuk jawaban yang positif skornya akan semakin tinggi, dan untuk jawaban yang negatif skornya akan semakin rendah, begitu juga sebaliknya pada pernyataan yang unfavorable. Setelah kedua variabel tersebut diukur, maka dapat digunakan untuk menjawab tujuan dari penelitian ini, yaitu untuk mengetahui peran kepemimpinan kepala sekolah sebagai supervisor akademik dan kinerja guru di SMK PGRI Tanjung Raja, dan untuk mengetahui hubungan antara kepemimpinan kepala sekolah terhadap kinerja guru. Tujuan penelitian tersebut dituangkan dalam bentuk hipotesis untuk kemudian diuji dengan menggunakan teknik analisis regresi pada Software SPSS 24.0. Uraian tentang statistik deskriptif yang meliputi nilai mean, median, modus, dan standar deviation akan disajikan secara rinci untuk masing-masing variabel. Berikut hasil dari statistik deskriptif untuk masing-masing variabel:

\section{a. Kepemimpinan Kepala Sekolah}

Kuesioner untuk variabel kepemimpinan kepala sekolah terdiri dari 40 butir pertanyaan.
Skor jawaban yang tertinggi adalah 4 dan skor jawaban yang terendah adalah 1, sehingga kemungkinan skor tertinggi yang hendak dicapai adalah $40 \times 4=160$ dan skor terendah adalah $40 \times 1=40$. Dari hasil pengumpulan data yang telah dilakukan maka diperoleh hasil skor tertinggi untuk variabel kepemimpinan kepala sekolah sebesar 160 dan skor terendah 40. Hasil analisis statistik deskriptif hitung diperoleh nilai mean sebesar 1,3132; standar deviation sebesar 13,47753. Variabel fungsi kepemimpinan kepala sekolah terdiri dari lima dimensi: (1). Karisma Kepala Sekolah, (2). Idealisme Kepala Sekolah, (3). Motivasi Inspirasi Kepala Sekolah, (4) Intelektual Kepala Sekolah, dan (5). Kepedulian terhadap individu guru. Masing-masing fungsi tersebut kemudian dikategorikan menjadi empat kategori, yaitu kategori tinggi, sedang, cukup, dan rendah. Berikut hasil kategori kelima fungsi kepemimpinan kepala sekolah pada penelitian ini.

Tabel 2. Hasil Kategori Fungsi Karisma

\begin{tabular}{ccccc}
\multicolumn{5}{c}{ Kepala Sekolah } \\
\hline No. & Kategori & F & Interval & $\%$ \\
\hline 1 & Tinggi & 30 & $82 \%-100 \%$ & $50 \%$ \\
2 & Sedang & 30 & $63 \%-81 \%$ & $50 \%$ \\
3 & Cukup & 0 & $44 \%-62 \%$ & $0 \%$ \\
4 & Rendah & 0 & $25 \%-43 \%$ & $0 \%$ \\
& Jumlah & 60 & Jumlah & $100 \%$ \\
\hline
\end{tabular}

Berdasarkan tabel di atas dapat diketahui bahwa fungsi karisma kepemimpinan kepala sekolah sebagian besar 
berada pada kategori sedang (50\%), sedangkan yang lainnya berada pada kategori tinggi $(50 \%)$.

Tabel 3. Hasil Kategori Fungsi Idealisme

\begin{tabular}{ccccc}
\multicolumn{5}{c}{ Kepala Sekolah } \\
\hline No. & Kategori & F & Interval & $\%$ \\
\hline 1 & Tinggi & 30 & $82 \%-100 \%$ & $50 \%$ \\
2 & Sedang & 28 & $63 \%-81 \%$ & $47 \%$ \\
3 & Cukup & 2 & $44 \%-62 \%$ & $3 \%$ \\
4 & Rendah & 0 & $25 \%-43 \%$ & $0 \%$ \\
\multicolumn{6}{c}{ Jumlah } & 60 & Jumlah & $100 \%$ \\
\hline \multicolumn{6}{l}{ Berdasarkan } & tabel di & atas dapat
\end{tabular}

diketahui bahwa fungsi idealisme kepemimpinan kepala sekolah sebagian besar berada pada kategori sedang (47\%), sedangkan yang lainnya berada pada kategori tinggi (50\%) dan kategori cukup (3\%).

Tabel 4. Hasil Kategori Fungsi Motivasi Inspirasional Kepala Sekolah

\begin{tabular}{ccccc}
\hline No. & Kategori & $\mathrm{F}$ & Interval & $\%$ \\
\hline 1 & Tinggi & 30 & $82 \%-100 \%$ & $50 \%$ \\
2 & Sedang & 29 & $63 \%-81 \%$ & $48 \%$ \\
3 & Cukup & 1 & $44 \%-62 \%$ & $2 \%$ \\
4 & Rendah & 0 & $25 \%-43 \%$ & $0 \%$ \\
& Jumlah & 60 & Jumlah & $100 \%$
\end{tabular}

Berdasarkan tabel di atas dapat diketahui bahwa fungsi motivasi inspirasional kepemimpinan kepala sekolah sebagian besar berada pada kategori tinggi (50\%), sedangkan yang lainnya berada pada kategori sedang (48\%) dan kategori cukup (2\%).
Tabel 5. Hasil Kategori Fungsi Intelektual Kepala Sekolah

\begin{tabular}{ccccc}
\hline No. & Kategori & F & Interval & $\%$ \\
\hline 1 & Tinggi & 29 & $82 \%-100 \%$ & $48 \%$ \\
2 & Sedang & 27 & $63 \%-81 \%$ & $45 \%$ \\
3 & Cukup & 4 & $44 \%-62 \%$ & $7 \%$ \\
4 & Rendah & 0 & $25 \%-43 \%$ & $0 \%$ \\
& Jumlah & 60 & Jumlah & $100 \%$
\end{tabular}

Berdasarkan tabel di atas dapat diketahui bahwa fungsi intelektual kepemimpinan kepala sekolah sebagian besar berada pada kategori tinggi (48\%), sedangkan yang lainnya berada pada kategori sedang (45\%) dan kategori cukup (7\%).

Tabel 6. Hasil Kategori Fungsi Kepedulian Kepala Sekolah

\begin{tabular}{|c|c|c|c|c|}
\hline No. & Kategori & $\mathrm{F}$ & Interval & $\%$ \\
\hline 1 & Tinggi & 27 & ;2 82\%-100\% & $45 \%$ \\
\hline 2 & Sedang & 25 & $63 \%-81 \%$ & $42 \%$ \\
\hline 3 & Cukup & 8 & $44 \%-62 \%$ & $13 \%$ \\
\hline 4 & Rendah & 0 & $25 \%-43 \%$ & $0 \%$ \\
\hline \multicolumn{2}{|r|}{ Jumlah } & 60 & Jumlah & $100 \%$ \\
\hline
\end{tabular}

Berdasarkan tabel di atas dapat diketahui bahwa fungsi kepedulian kepemimpinan kepala sekolah sebagian besar berada pada kategori tinggi (45\%), sedangkan yang lainnya berada pada kategori sedang (42\%) dan kategori cukup (13\%). Secara keseluruhan variabel kepemimpinan kepala sekolah dikategorikan menjadi empat kategori yaitu kategori tinggi, sedang, cukup, dan rendah. Hasil kategori data selengkapnya dapat dilihat seperti pada tabel berikut. 
Tabel 7. Hasil Kategori Kepemimpinan Kepala Sekolah

\begin{tabular}{ccccc}
\hline No. & Kategori & F & Interval & $\%$ \\
\hline 1 & Tinggi & 31 & $82 \%-100 \%$ & $52 \%$ \\
2 & Sedang & 29 & $63 \%-81 \%$ & $48 \%$ \\
3 & Cukup & 0 & $44 \%-62 \%$ & $0 \%$ \\
4 & Rendah & 0 & $25 \%-43 \%$ & $0 \%$ \\
& Jumlah & 60 & Jumlah & $100 \%$
\end{tabular}

Tabel di atas menunjukkan bahwa sebagian besar responden yaitu sebanyak 31 responden atau sebesar $52 \%$ mempunyai penilaian tentang kualitas kepemimpinan kepala sekolah pada kategori tinggi, yang mempunyai penilaian tentang kualitas kepemimpinan kepala sekolah pada kategori sedang sebanyak 29 responden atau sebesar $48 \%$ dari total responden yang merupakan guru SMK PGRI Tanjung Raja. Dari tabel di atas terlihat bahwa yang mempunyai penilaian tentang kualitas kepemimpinan kepala sekolah untuk kategori cukup dan kategori rendah sebesar $0 \%$

\section{b. Kinerja Guru}

Kinerja guru diukur dengan menggunakan instrumen penelitian berupa kuesioner yang diberikan kepada 60 guru yang merupakan anggota populasi dari guru-guru SMK PGRI Tanjung Raja sebanyak 60 butir pertanyaan. Jawaban dari kuesioner tersebut menggunakan skala likert, dimana jawaban sangat sesuai untuk pertanyaan yang favorable mempunyai skor 4, sesuai skornya 3, tidak sesuai skornya 2, sangat tidak sesuai skornya 1 , begitu juga sebaliknya untuk pertanyaan yang unfavorable. Berdasarkan banyaknya butir soal dan skor untuk masing-masing jawaban, maka kemungkinan skor tertinggi yang hendak dicapai oleh kinerja guru adalah 240 dan skor terendah adalah 60. Dari hasil pengumpulan data yang telah dilakukan diperoleh hasil skor tertinggi sebesar 240 dan skor terendah sebesar 155. Hasil analisis statistik deskriptif hitung diperoleh nilai mean sebesar 2,0265; standar deviation sebesar 22,49431. Kinerja guru diukur dari aspek perencanaan, pelaksanaan, penilaian, dan tindak lanjut penilaian hasil pembelajaran. Aspek kinerja tersebut dikategorikan ke dalam empat kategori, yaitu tinggi, sedang, cukup, dan rendah. Berikut hasil kategori untuk masing-masing aspek kinerja tersebut.

Tabel 8. Hasil Kategori Aspek Perencanaan

\begin{tabular}{ccccc}
\multicolumn{5}{c}{ Pembelajaran } \\
\hline No. & Kategori & F & Interval & $\%$ \\
\hline 1 & Tinggi & 30 & $82 \%-100 \%$ & $50 \%$ \\
2 & Sedang & 30 & $63 \%-81 \%$ & $50 \%$ \\
3 & Cukup & 0 & $44 \%-62 \%$ & $0 \%$ \\
4 & Rendah & 0 & $25 \%-43 \%$ & $0 \%$ \\
& Jumlah & 60 & Jumlah & $100 \%$
\end{tabular}

Berdasarkan tabel di atas dapat diketahui bahwa aspek perencanaan pembelajaran sebagian besar berada pada kategori tinggi (50\%), sedangkan yang lainnya berada pada kategori sedang (50\%). 
Tabel 9. Hasil Kategori Aspek Pelaksanaan Pembelajaran

\begin{tabular}{ccccc}
\hline No. & Kategori & F & Interval & $\%$ \\
\hline 1 & Tinggi & 32 & $82 \%-100 \%$ & $53 \%$ \\
2 & Sedang & 28 & $63 \%-81 \%$ & $47 \%$ \\
3 & Cukup & 0 & $44 \%-62 \%$ & $0 \%$ \\
4 & Rendah & 0 & $25 \%-43 \%$ & $0 \%$ \\
& Jumlah & 60 & Jumlah & $100 \%$
\end{tabular}

Berdasarkan tabel di atas dapat diketahui bahwa aspek pelaksanaan pembelajaran sebagian besar berada pada kategori tinggi (53\%), sedangkan yang lainnya berada pada kategori sedang (47\%).

Tabel 10. Hasil Kategori Aspek Penilaian

\begin{tabular}{ccccc}
\multicolumn{5}{c}{ Pembelajaran } \\
\hline No. & Kategori & F & Interval & $\%$ \\
\hline 1 & Tinggi & 25 & $82 \%-100 \%$ & $42 \%$ \\
2 & Sedang & 26 & $63 \%-81 \%$ & $43 \%$ \\
3 & Cukup & 9 & $44 \%-62 \%$ & $15 \%$ \\
4 & Rendah & 0 & $25 \%-43 \%$ & $0 \%$ \\
\multicolumn{2}{c}{ Jumlah } & 60 & Jumlah & $100 \%$
\end{tabular}

Berdasarkan tabel di atas dapat diketahui bahwa aspek penilaian pembelajaran sebagian besar berada pada kategori sedang (43\%), sedangkan yang lainnya berada pada kategori tinggi (42\%) dan kategori cukup (15\%).

Tabel 11. Hasil Kategori Aspek Tindak Lanjut Penilaian Hasil Pembelajaran

\begin{tabular}{lcccc}
\hline No. & Kategori & $\mathbf{F}$ & Interval & $\%$ \\
\hline 1 & Tinggi & 31 & $82 \%-100 \%$ & $52 \%$ \\
2 & Sedang & 27 & $63 \%-81 \%$ & $45 \%$ \\
3 & Cukup & 2 & $44 \%-62 \%$ & $3 \%$ \\
4 & Rendah & 0 & $25 \%-43 \%$ & $0 \%$ \\
& Jumlah & 60 & Jumlah & $100 \%$
\end{tabular}

Berdasarkan tabel di atas dapat diketahui bahwa aspek tindak lanjut hasil pembelajaran sebagian besar berada pada kategori sedang (45\%), sedangkan yang lainnya berada pada kategori tinggi (52\%) dan kategori cukup (3\%). Secara keseluruhan variabel kinerja guru yang dikategorikan menjadi empat kategori yaitu kategori tinggi, sedang, cukup, dan rendah, hasil kategori data selengkapnya dapat dilihat pada tabel berikut ini:

Tabel 12. Hasil Kategori Kinerja Guru

\begin{tabular}{lrccc}
\hline No. & Kategori & $\mathrm{F}$ & Interval & $\%$ \\
\hline 1 & Tinggi & 31 & $82 \%-100 \%$ & $52 \%$ \\
2 & Sedang & 27 & $63 \%-81 \%$ & $45 \%$ \\
3 & Cukup & 2 & $44 \%-62 \%$ & $3 \%$ \\
4 & Rendah & 0 & $25 \%-43 \%$ & $0 \%$ \\
& Jumlah & 60 & Jumlah & $.00 \%$ \\
\hline
\end{tabular}

Tabel di atas menunjukkan bahwa dari 60 guru SMK PGRI Tanjung Raja yang menjadi responden dalam penelitian ini, sebagian besar diantaranya yaitu sebanyak 31 atau sebesar $52 \%$ guru memiliki kinerja pada kategori tinggi. Sebanyak 27 guru atau sebesar $45 \%$ guru memiliki kinerja pada kategori sedang dari total responden yang merupakan guru SMK PGRI Tanjung Raja. Sedangkan banyaknya guru yang memiliki kinerja pada kategori cukup yaitu 2 guru atau sebesar $3 \%$ dan pada kategori rendah sebanyak nol orang atau $0 \%$.

\section{B. Pengujian Persyaratan Analisis}

Dalam penelitian ini digunakan analisis regresi. Untuk itu, perlu dilakukan pengujian 
persyaratan analisis yang berupa uji normalitas sebaran, dan uji linearitas.

a. Uji Normalitas Sebaran

Salah satu syarat untuk menganalisis data adalah dengan melakukan uji normalitas sebaran. Uji normalitas sebaran dilakukan untuk menguji apakah data pada masingmasing variabel penelitian terdistribusi normal atau tidak. Teknik analisis yang digunakan adalah chi-square. Menggunakan SPSS 24.00. Taraf signifikansi yang digunakan sebesar $=$ 0,05 (p-value > 0,05). Berikut adalah hasil penghitungan untuk semua variabel yang disajikan pada tabel berikut ini:

Tabel 13. Hasil Uji Normalitas Sebaran

\begin{tabular}{ccccc}
\hline Variabel & $\mathbf{\chi}_{\text {tabel }}^{2}$ & $\mathbf{\chi}_{\text {hitung }}$ & p-value & $\begin{array}{c}\text { Kesimp } \\
\text { ulan }\end{array}$ \\
\hline $\begin{array}{c}\text { Kepemimpinan } \\
\text { Kepala } \\
\text { Sekolah (X) } \\
\text { Kinerja }\end{array}$ & $\chi_{\substack{(4 ; 0,05) \\
9,488}}^{2}=$ & 4,101 & 0,689 & Normal \\
guru (Y) & $\chi_{\substack{(4 ; 0,05) \\
9,488}}^{2}=$ & & & \\
\hline
\end{tabular}

Berdasarkan tabel diatas, dapat dilihat bahwa untuk masing-masing variabel nilai $\chi_{\text {hitung }}^{2}$ lebih kecil dari nilai $\chi_{\text {tabel }}^{2}$ maka variabel tersebut berdistribusi normal. Kesimpulan yang sama juga dapat dilihat dari nilai $\mathrm{p}$-value tiap-tiap variabel berada diatas taraf signifikansi yang ditetapkan yaitu 0,05 . Dengan demikian, dapat disimpulkan bahwa sebaran kedua variabel penelitian ini adalah normal, sehingga dinyatakan mempunyai asumsi normalitas dan memenuhi syarat agar dapat dianalisis lebih lanjut.

b. Uji Linearitas

Uji ini dilakukan untuk mengetahui apakah variabel bebas $(\mathrm{X})$ dan variabel terikat (Y) mempunyai hubungan yang linier. Untuk mengujinya dilakukan dengan uji $F$ penyimpangan data dari garis linier (deviation from linierity) yang digunakan untuk memprediksikan model. Kriteria yang digunakan untuk menguji Linearitas adalah jika nilai $\mathrm{p}$ pada uji regresi menunjukkan hasil yang tidak signifikan $(<0,05)$, maka disimpulkan korelasi yang diuji mempunyai model linier, sebaliknya jika hasil signifikansi hasilnya signifikan maka dapat disimpulkan terjadi hubungan yang tidak linier. Atau dapat menggunakan cara lain yaitu dengan membandingkan nilai Fhitung dengan F tabel, yaitu apabila nilai $\mathrm{F}_{\text {hitung }}<\mathrm{F}_{\text {tabel }}$ maka terjadi korelasi yang linier.

Tabel 14. Hasil Uji Linearitas

\begin{tabular}{ccccc}
\hline Variabel & $\mathrm{F}_{\text {hitung }}$ & $\mathrm{F}_{\text {tabel }}$ & p-value & Ket. \\
\hline $\begin{array}{c}\text { Kepemimpinan } \\
\text { kepala sekolah } \\
\text { dengan kinerja } \\
\text { guru }\end{array}$ & 1,124 & 3,92 & 0,026 & Linier \\
\hline
\end{tabular}

Berdasarkan tabel di atas, terlihat bahwa nilai p korelasi antara variabel kepemimpinan kepala sekolah dengan kinerja guru sebesar 0,026, hasil tersebut menunjukkan tidak signifikan. Nilai signifikansi $p>0,05(0,913>$ 0,05), maka dapat disimpulkan bahwa korelasi 
antara kepemimpinan kepala sekolah dengan kinerja guru adalah linier.

\section{Pengujian Hipotesis Statistik}

Hipotesis yang diajukan dalam penelitian ini (Ha) berbunyi kepemimpinan kepala sekolah sebagai supervisor akademik berpengaruh secara signifikan terhadap kinerja untuk keperluan pengujian hipotesis statistik, maka hipotesis nihil (Ho) yang berbunyi kepemimpinan kepala sekolah sebagai supervisor akademik tidak berpengaruh secara signifikan terhadap kinerja guru SMK PGRI Tanjung Raja.

Ho ditolak jika jika $\mathrm{F}_{\text {hitung }}>\mathrm{F}_{\text {tabel }}$. Hasil pengujian hipotesis dijelaskan sebagai berikut: Tabel 15. Ringkasan Hasil Analisis Regresi guru SMK PGRI Tanjung Raja. Kemudian

(Ho) yang menyatakan bahwa kepemimpinan kepala sekolah tidak berpengaruh secara signifikan terhadap kinerja guru SMK PGRI Tanjung Raja, ditolak. Ini berarti hipotesis penelitian (Ha) diterima, yaitu kepemimpinan kepala sekolah berpengaruh secara signifikan terhadap kinerja guru SMK PGRI Tanjung Raja. Koefisien korelasi $(r)=80,7 \%$ artinya antara kepemimpinan kepala sekolah dengan kinerja guru terdapat hubungan yang cukup kuat. Angka positif pada koefisien korelasi tersebut menunjukkan bahwa antara variabel kepemimpinan kepala sekolah (X)dengan kinerja guru (Y) memiliki korelasi yang positif dan searah. Dengan demikian dapat diinterpretasikan bahwa semakin tinggi tingkat kepemimpinan kepala sekolah maka semakin tinggi pula kinerja guru.

Untuk mengetahui seberapa besar kontribusi variabel bebas terhadap variabel terikat atau sumbangan efektif kepemimpinan

Berdasarkan perhitungan dengan dengan menggunakan uji $\mathrm{F}$ diperoleh $\mathrm{F}=0,05$ adalah 3,92. Hasil konsultasi menunjukkan bahwa harga $\mathrm{F}_{\text {hitung }}$ sebesar 108,133. Untuk menguji apakah nilai signifikan, maka dikonsultasikan dengan harga $\mathrm{F}_{\text {tabel }}$. Nilai $\mathrm{F}_{\text {tabel }}$ dengan dengan $\mathrm{db}$ pembilang 1 dan $\mathrm{db}$ penyebut 145 pada taraf signifikansi $i_{\text {hitung }}$ lebih besar dari nilai $F_{\text {tabel }}(108,133>3,92)$. Hasil tersebut menunjukkan bahwa hipotesis nihil kepala sekolah terhadap kinerja guru dapat dilihat dari $\mathrm{R}^{2}$ yang terlihat pada tabel di atas. $\mathrm{R}^{2}$ sebesar 65,1 \%berarti bahwa variabel kepemimpinan kepala sekolah mampu menjelaskan variabel kinerja guru sebesar $65,1 \%$, sedangkan $80,7 \%$ yang lainnya dipengaruhi oleh variabel lain yang tidak memprediksi seberapa jauh perubahan variabel terikat, bila nilai variabel bebas dimanipulasi atau diubah-ubah, maka ditentukan dengan termasuk dalam penelitian ini. Untuk 
persamaan regresi. Bentuk persamaan regresi untuk memprediksi seberapa jauh perubahan variabel kinerja guru (Y) bilai nilai variabel kepemimpinan kepala sekolah (X) dimanipulasi adalah: $\mathrm{Y}=\mathrm{a}+\mathrm{bX}$. Berdasarkanhasil analisis regresi pada tabel di atas, maka persamaan regresinya adalah: $\mathrm{Y}=$ 33,360+0,483X Koefisien regresi sebesar 0,483 menyatakan bahwa setiap penambahan satu skor atau nilai kepemimpinan kepala sekolah dapat meningkatkan nilai atau skor kinerja guru sebesar 0,483 pada konstanta 33,360; berarti konstanta sebesar 33,360 menunjukkan apabila skor variabel kepemimpinan kepala sekolah dianggap tidak ada (nol), maka skor kinerja guru nilainya sebesar 33,360.

\section{PEMBAHASAN}

Hasil penelitian ini mengungkapkan bahwa :

\section{Kepemimpinan Kepala SMK PGRI Tanjung Raja.}

Salah satu tugas kepala sekolah adalah sebagai pemimpin pendidikan, yaitu memimpin staff (guru-guru, pegawai dan pesuruh), membina kerjasama yang harmonis antar anggota staf sehinggga dapat membangkitkan semangat kerja, motivasi kerja bagi staf yang dipimpin serta menciptakan suasana yang konduktif. Kepemimpinan yang bagus, kerjasama yang harmonis serta suasana yang konduktif menjamin staf menjadi senang untuk melaksanakan tugas dengan sebaik-baiknya. Disamping itu kepemimpinan kepala sekolah merupakan kunci proses pemberdayaan kegiatan pendidikan di sekolah. Unsur kepemimpinan kepala sekolah adalah pengaruh yang dimilikinya dan kemampuan menggunakan pengaruh tersebut serta akibat pengaruh itu bagi orang yang hendak dipengaruhi yaitu para guru, pegawai, dan warga sekolah lainnya. Pengaruh tersebut diwujudkan melalui fungsi kepemimpinan kepala sekolah sebagai supervisor akademik yaitu charisma, idealized influence, inspirational motivation, intellectual stimulation, individual consideration. Pengelolaaan fungsi kepemimpinan kepala sekolah tersebut dapat memberikan pengaruh terhadap kinerja guru, dengan demikian keberhasilan tujuan pendidikan akan mudah tercapai. Fungsi kepemimpinan karisma kepala sekolah dapat dilihat dari sikap kepala sekolah di SMK PGRI Tanjung Raja, yaitu keteladanan, dapat dipercaya, mampu mengemban amanah, dihormati oleh sesama warga sekolah, dan dapat mengambil keputusan terbaik untuk kepentingan sekolah. Kepala sekolah yang dinilai guru memiliki kelima sikap tersebut dapat dikatakan bahwa kepala sekolah tersebut mempunyai karisma dimata guru-guru. Berdasarkan beberapa indikator tersebut, fungsi kepemimpinan karisma kepala sekolah dalam penelitian ini 
sebagian besar tergolong pada kategori tinggi (50\%). Selain berkarisma, kepemimpinan juga dapat dilihat dari kemampuan kepala sekolah untuk mempengaruhi idealisme para guru yang dibawahi tentunya dalam hal yang positif. Kepala sekolah yang mempunyai kepemimpinan yang mampu mempengaruhi idealisme para guru dalam hal yang positif dapat diketahui melalui beberapa tolak ukur, yaitu mengawal ketercapaian visi organisasi yang jelas, dan mampu mengkomunikasikan visi, misi, dan tujuan organisasi yang jelas.

\section{Berdasarkan beberapa indikator} tersebut, fungsi kepemimpinan mempengaruhi idealisme kepala sekolah dalam penelitian ini sebagian besar tergolong pada kategori tinggi (50\%). Kepala sekolah yang mempunyai kepemimpinan yang baik juga dapat diketahui dari kemampuannya untuk memotivasi guru sehingga menjadi lebih semangat. Motivasi ini terlihat dari bentuk sikap kepala sekolah yang selalu memberikan dukungan terhadap gagasan guru, memberikan dorongan semangat, dan selalu menjadi inspirasi bagi guru, karyawan, dan siswa. Berdasarkan beberapa indikator tersebut, fungsi kepemimpinan motivasi inspirasional kepala sekolah dalam penelitian ini sebagian besar tergolong pada kategori tinggi (50\%). Kepemimpinan dalam penelitian ini juga dilihat dari stimulus intelektual dari seorang kepala sekolah. Stimulus intelektual ini dapat diketahui dengan melihat beberapa indikator, yaitu adanya sikap kepala sekolah yang memberikan hak sama bagi setiap guru, menumbuhkan inovasi, mendukung cara kerja guru, melibatkan partisipasi guru dalam menyelesaikan masalah, dan memiliki kecerdasan/intelektual. Berdasarkan beberapa indikator tersebut, fungsi kepemimpinan stimulus intelektual kepala sekolah dalam penelitian ini sebagian besar tergolong pada kategori tinggi (48\%).

Fungsi kepemimpinan kepala sekolah yang terakhir pada penelitian ini adalah kepedulian. Kepedulian kepala sekolah dapat diketahui dalam memberikan bimbingan dan nasehat kepada guru, karyawan, dan siswa. Berdasarkan beberapa indikator tersebut, fungsi kepemimpinan kepedulian individual kepala sekolah dalam penelitian ini sebagian besar tergolong pada kategori tinggi (52\%).

Pada penelitian ini dideskripsikan kualitas kepemimpinan kepala sekolah berdasarkan penilaian dari guru SMK PGRI Tanjung Raja. Kepemimpinan kepala sekolah dinilai berdasarkan aspek kharisma, pengaruh idealisme, motivasi yang inspiratif, rangsangan intelektual kepada guru, dan kepedulian terhadap individu guru. Berdasarkan hasil penelitian diketahui bahwa kualitas kepemimpinan kepala sekolah dinilai oleh sebagian besar guru SMK PGRI Tanjung Raja berada pada kategori tinggi (52\%), sedangkan 
yang lainnya menilai kepemimpinan kepala sekolah berada pada kategori sedang (48\%). Hasil penelitian ini menunjukkan adanya indikasi yang positif karena sebagian besar guru memberi penilaian yang positif tentang kualitas kepemimpinan kepala sekolah. Penilaian yang positif dari para guru tersebut dapat menjadi cerminan bahwa kepala sekolah telah berhasil menjadi pemimpin yang baik bagi para guru SMK PGRI Tanjung Raja, sehingga mampu mengantarkan sekolah yang dipimpinannya menuju tujuan utama dari pendidikan, yaitu menciptakan sumberdaya manusia yang berkualitas.

\section{Kinerja Guru SMK PGRI Tanjung Raja}

Pada institusi pendidikan, peran penting selain diemban oleh kepala sekolah juga dipegang oleh seorang guru. Jika kepala sekolah lebih berfungsi dalam hal manajerial, peran guru lebih mendominasi tentang aspek pembelajaran, yaitu mulai dari perencanaan, pelaksanaan, penilaian hasil belajar, dan pelaksanaan tindak lanjut hasil penilaian. Berdasarkan keempat tahap pembelajaran itulah kinerja dari seorang guru dapat diukur. Pada tahap perencanaan pembelajaran, seorang guru dituntut untuk dapat merumuskan tujuan pembelajaran, pemilihan dan pengorganisasian materi ajar, pemilihan media/alat pembelajaran, skenario/kegiatan pembelajaran, pemilihan sumber belajar, dan penilaian hasil belajar. Keahlian serta pengalaman yang dimiliki oleh seorang guru akan dapat membuat perencanaan yang baik dan sesuai dengan kebutuhan dari peserta didik, sehingga perencanaan yang sesuai akan menentukan keberhasilan dari pembelajaran. Keahlian guru pada tahap ini perlu adanya kemampuan untuk merumuskan tujuan pembelajaran dan dituntut untuk tepat, sedangkan pengalaman guru dapat ditinjau dari masa kerja seorang guru dan juga jam kerja yang telah dilakukan oleh guru. Berdasarkan hasil penelitian dapat diketahui bahwa tahap perencanaan pembelajaran sebagian besar berada pada kategori tinggi $(50 \%)$.

Pada tahap pelaksanaan pembelajaran, seorang guru dituntut untuk memiliki kemampuan membuka pelajaran, menguasai materi pelajaran, interaksi pembelajaran, sikap guru dalam proses pembelajaran, melakukan evaluasi pembelajaran, dan kemampuan menutup pembelajaran. Apabila pada tahap perencanaan dituntut untuk dapat merumuskan pembelajaran, pada tahap ini seorang guru dituntut untuk dapat mengaplikasikan hal-hal yang telah direncanakan, sehingga pelaksanaan pembelajaran yang ideal adalah yang sesuai dengan yang telah direncanakan. Namun terkadang hal tersebut tidak terjadi karena terjadi hal-hal diluar yang direncanakan. Pada saat seperti itu kebijaksanaan dan pengalaman guru sangat berperan sehingga proses pembelajaran tidak 
jauh melenceng dari apa yang telah direncanakan. Berdasarkan hasil penelitian dapat diketahui bahwa tahap pelaksanaan pembelajaran sebagian besar berada pada kategori tinggi (53\%). Tahapan selanjutnya yang harus dikuasai oleh seorang guru adalah tentang penilaian hasil belajar dan tindak lanjut hasil penilaian. Tahap penilaian merupakan tahapan yang paling sulit karena pada tahap ini seorang guru dituntut untuk memberikan penilaian yang objektif terhadap siswa berdasarkan hasil tes dan tugas-tugas yang diberikan selama proses pelaksanaan pembelajaran. Setelah tahapan penilaian, seorang guru juga harus dapat melakukan analisis hasil penilaian untuk menentukan tindak lanjut dari hasil penilaian tersebut. Hasil penilaian dapat digunakan sebagai bahan evaluasi guru untuk perbaikan di waktu yang akan datang. Berdasarkan hasil penelitian dapat diketahui bahwa tahap tindak lanjut penilaian pembelajaran sebagian besar berada pada kategori tinggi (52\%).

Pada penelitian ini dinilai kinerja berdasarkan keempat tahapan tersebut. Hasil penelitian menunjukkan bahwa sebagian besar guru SMK PGRI Tanjung Raja yang menjadi responden, yaitu sebesar 52\% mempunyai kinerja yang tinggi, sedangkan selebihnya yaitu sebesar45\% mempunyai kinerja yang berada dalam kategori sedang. Berdasarkan hasil tersebut dapat diintepretasikan bahwa kinerja guru cukup baik. Hasil penelitian menunjukkan suatu indikasi yang positif, yaitu memberi gambaran mengenai kinerja guruguru SMK PGRI Tanjung Raja yang sebagian besar mempunyai kinerja yang tinggi. Berdasarkan hasil penelitian dapat diketahui bahwa tahap perencanaan pembelajaran sebagian besar berada pada kategori tinggi $(50 \%)$.

\section{Pengaruh Kepemimpinan Kepala Sekolah terhadap Kinerja Guru SMK PGRI Tanjung Raja}

Hipotesis pada penelitian ini yang menyatakan bahwa kepemimpinan kepala sekolah berpengaruh secara signifikan terhadap kinerja guru SMK PGRI Tanjung Raja, berdasarkan hasil penelitian diterima. Hal ini ditunjukkan dengan nilai signifikansi pada uji regresi yang lebih kecil dari taraf signifikansi, yaitu $<0,05$ dan nilai $\mathrm{F}_{\text {hitung }}$ yang lebih besar dari $\mathrm{F}_{\text {tabel, }}$ yaitu 108,133> 3,92. Hasil penelitian yang menunjukkan bahwa kepemimpinan kepala sekolah berpengaruh secara signifikan terhadap kinerja guru SMK PGRI Tanjung Raja yang dibuktikan secara statistik juga diperkuat oleh hasil kategori pada kategori tersebut, dimana keduanya samasama berada pada kategori sedang dan cukup. Kepemimpinan kepala sekolah dinilai oleh guru SMK PGRI Tanjung Raja berada pada kategori tinggi sebesar 52\% dan berada pada kategori sedang sebesar $48 \%$, dan untuk 
variabel kinerja guru pada penelitian ini termasuk dalam kategori tinggi sebesar 52\% dan berada pada kategori sedang sebesar $45 \%$. Berdasarkan hasil uji statistik dan hasil kategori kedua variabel tersebut dapat disimpulkan bahwa semakin tinggi kualitas kepemimpinan kepala sekolah akan diikuti oleh peningkatan kinerja guru. Kepemimpinan kepala sekolah mempunyai sumbangan efektif terhadap kinerja guru sebesar 0,651, yang berarti bahwa kepemimpinan kepala sekolah mampu menjelaskan variabel kinerja guru sebesar $65,1 \%$, sedangkan $80,7 \%$ yang lainnya dipengaruhi oleh variabel lain yang tidak termasuk dalam penelitian ini. Hasil penelitian ini yang menyatakan bahwa kepemimpinan kepala sekolah berpengaruh secara signifikan terhadap kinerja guru SMK PGRI Tanjung Raja. Semakin tinggi kepemimpinan kepala sekolah semakin tinggi pula kinerja guru, namun sebaliknya semakin rendah kepemimpinan kepala sekolah mengakibatkan kinerja guru menjadi rendah.

\section{KESIMPULAN}

Berdasarkan hasil penelitian dan pembahasan dapat disimpulkan sebagai berikut: 1. Kepemimpinan kepala sekolah yang diukur menggunakan aspek karisma, pengaruh idealisme, motivasi yang inspiratif bagi guru, rangsangan intelektual kepada guru, dan kepedulian terhadap individu guru, persepsi oleh guru SMK PGRI Tanjung Raja pada penelitian ini berada pada kategori tinggi sebesar 52\% (31 guru) dan pada kategori sedang sebesar 48\% (29 guru), 2. Kinerja guru SMK PGRI Tanjung Raja yang dinilai pada tahap perencanaan, pelaksanaan, penilaian, dan tindak lanjut hasil penilaian pembelajaran, pada penelitian ini $52 \%$ guru berada pada kategori tinggi dan $45 \%$ pada kategori sedang, 3. Kepemimpinan kepala sekolah berpengaruh secara signifikan terhadap kinerja guru SMK PGRI Tanjung Raja sehingga tinggi rendahnya kualitas kepemimpinan kepala sekolah akan berpengaruh terhadap tinggi rendahnya kinerja guru. Hal tersebut ditunjukkan dengan uji regresi yang lebih kecil dari taraf signifikansi, yaitu $<0,05$ dan nilai $\mathrm{F}_{\text {hitung }}$ lebih besar dari $\mathrm{F}_{\text {tabel' }}$ yaitu 108,133> 3,92. Koefisien $\mathrm{R}^{2}$ sebesar 0,651 berarti variabel kepemimpinan kepala sekolah mampu menjelaskan variabel kinerja guru sebesar 65,1\%, kebermaknaan $80,7 \%$ yang lainnya diperkirakan dipengaruhi oleh variabel lain yang tidak diungkap dalam penelitian ini seperti pengetahuan guru, kepribadian guru, dedikasi, pengembangan profesi, dan lain sebagainya.

\section{DAFTAR PUSTAKA}

Arikunto, Suharsimi. (2002). Prosedur Penelitian, Suatu Pendekatan Praktik. Jakarta: PT. Rineka Cipta.

$\begin{array}{ccr}\text { Arimbi, } \quad \text { Vela. } & \text { (2011). } & \text { Pengaruh } \\ \text { Kepemimpinan } & \text { Kepala } & \text { Sekolah } \\ \text { Terhadap Kinerja Guru } & \text { Sekolah }\end{array}$


Menengah Kejuruan (SMK) Negeri di Temanggung. Yogyakarta: UNY

Fredikus Djelahu Maighoaku. (2010). Sumbangan kepemimpinan kepala sekolah, iklim sekolah, dan kompetensi guru terhadap kinerja guru SMA di Kabupaten Manggarai Yogyakarta: Pascasarjana UNY.

F.X. Sudarsono. (1989). Beberapa dalam penelitian. Gadjahmada Press. Yogyakarta.

Gaffar, Fakry. (1987). Perencanaan Pendidikan. Jakarta: Depdikbud.

Hadari Nawawi dan M. Martini Hadari. (2005). Kepemimpinan yang efektif. Yogyakarta: Gadjahmada Press.

Imam Erfendi. (2005). Pengaruh pengalaman guru, motivasi dan kepemimpinan kepala Sekolah terhadap kinerja guru SD di Kecamatan Tenggarong Kabupaten Kutai Kartanegara. Yogyakarta: Pascasarjana UNY.

Kartini Kartono. (1990). Pemimpin dan kepemimpinan. Jakarta: Rajawali Press.

Mulyasa, E. (2004). Menjadi kepala sekolah profesional. Bandung: PT Remaja Rosdakarya.

Mulyasa, E. (2009). Menjadi Guru Profesional Menciptakan Pembelajaran Kreatif dan Menyenangkan. Bandung: PT Remaja Rosdakarya.

Olivia. (1987). Supervision for Todays School. Basic Principles. New York.

Permendiknas RI No. 13 tahun 2007 tentang standar kompetensi kepala sekolah dan buku mengenai Standar Kompetensi
Kepala Sekolah TK, SD, SMP, SMA, SMK\&SLB.

Purwanto, Heri. (1998). Pengantar Perilaku Manusia Untuk Keperawatan. Jakarta: PT EGC.

Riduwan. (2007). Skala pengukuran variabelvariabel penelitian. Bandung: Alfabeta.

Sahertian. (2000). Konsep Dasar dan Teknik Supervisi Pendidikan. Jakarta: PT Intimedia.

Soewadji Lazaruth. (1987). Kepala sekolah dan tanggung jawabnya. Yogyakarta: PT Kanisius.

Sri Kustilah. (2005). Kontribusi kesejahteraan guru, iklim kerja, dan kepemimpinan kepala sekolah terhadap kinerja guru IPS SMP di Kota Yogyakarta Tesis. Yogyakarta: UNY.

Sugiyono. (2007). Statistika untuk penelitian. Bandung: Alfabeta.

Sumadi Suryabrata. (2003). Metodologi penelitian. Jakarta: PT Grafindo.

Syaiful Sagala. 2010. Supervisi Pembelajaran dalam Profesi Pendidikan. Bandung: CV Alfabeta.

Wahab, Azis. 2009. Metode dan Model-model Mengajar. Bandung: Alfabeta.

Wahjosumidjo. 1994. Kepemimpinan dan Motivasi. Jakarta: PT Ghalia Indonesia.

Yuliandri, J., \& Kristiawan, M. (2017). Peran Kepemimpinan Kepala Sekolah Terhadap Peningkatan Kinerja Guru. Jurnal Dosen Universitas PGRI Palembang. 
